\title{
Pengaruh Profesionalisme, Kompetensi, dan Pengalaman Kerja Terhadap Kualitas Laporan Keuangan Badan Usaha Milik Desa di Kecamatan Sawan
}

\author{
Nyoman Oky Novianti Sari ${ }^{1 *}$, Edy Sujana $^{2}$ iD \\ ${ }^{12}$ Program Studi S1 Akuntansi, Jurusan Ekonomi dan Akuntansi , Universitas Pendidikan Ganesha, Singaraja, Bali, \\ Indonesia \\ *Okynovia10@gmail.com ${ }^{\text {* }}$
}

\section{Abstrak}

Penelitian ini bertujuan untuk mengetahui pengaruh profesionalisme, kompetensi, dan pengalaman kerja terhadap kualitas laporan keuangan Badan Usaha Milik Desa di Kecamatan Sawan. Populasi penelitian ini adalah seluruh karyawan yang bekerja di Badan Usaha Milik Desa se-Kecamatan Sawan sejumlah 137 orang, teknik sampel yang digunakan yaitu purposive sampling. Jumlah sampel dalam penelitian ini yaitu 39 responden. Teknik analisis data dalam penelitian ini adalah kuantitatif dengan menggunakan analisis regresi linier berganda yang diolah dengan bantuan program SPSS 20 for windows. Hasil dari penelitian menunjukkan bahwa (1) profesionalisme berpengaruh positif dan signifikan terhadap kualitas laporan keuangan,(2) kompetensi berpengaruh positif dan signifikan terhadap kualitas laporan keuangan, dan (3) pengalaman kerja berpengaruh positif dan signifikan terhadap kualitas laporan keuangan.

Kata Kunci : Kompetensi, Kualitas Laporan Keuangan, Pengalaman Kerja, Profesionalisme

\section{Abstract}

This study aims to see the influence professionalism, competence, and work experience of the financial statement of Vilage-owned Enterprises in Sawan Subdistrict. The population of this research is all employees who work in Vilage-owned Enterprises Sawan Subdistrict totaling 137 people, the sample technique used is purposive sampling. The number of samples in this study were 39 respondents. The data analysis technique in this research is quantitative using multiple linear regression analysis which is processed with the help of SPSS 20 for Windows. The results of the study indicate that 1) professionalism had a positive and significant effect toward the quality of financial statement,(2) competence had a positive and significant effect toward the quality of financial statement, and (3) work experience had a positive and significant effect toward the quality of financial statement.

Keywords: competence, professionalism, quality of financial statement, work experience

\section{Pendahuluan}

Kondisi Pandemi COVID-19 saat ini, menimbulkan pengaruh yang cukup signifikan terhadap pergerakan ekonomi di Indonesia. Pergerakan ekonomi saat ini sangatlah lemah terutama pada bidang pariwisata. Dalam kondisi seperti ini sangat diperlukan pembangunan untuk meningkatkan kesejahteraan kehidupan masyarakat. Karena struktur yang paling dekat dengan masyarakat adalah desa, maka desa memiliki peran penting dalam pembangunan agar nantinya dapat mensejahterakan masyarakat. Salah satu lokomotif pembangunan di desa adalah dengan mendirikan Badan Usaha Milik Desa atau disingkat BUM Des. Menurut Undang-Undang Nomor 6 Tahun 2014 Pasal 1 angka (6) menyebutkan bahwa "Badan Usaha

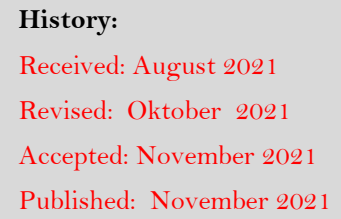


Milik Desa yang selanjutnya disebut BUM Desa, adalah badan usaha yang seluruh atau sebagian besar modalnya dimiliki oleh desa melalui penyertaan secara langsung yang berasal dari kekayaan desa yang dipisahkan guna mengelola aset, jasa pelayanan, dan usaha lainnya untuk sebesar-besarnya kesejahteraan masyarakat desa".

Badan Usaha Milik Desa di kecamatan sawan, saat ini hampir semua BUM Desanya mengandalkan kegiatan simpan pinjam sebagai usaha pokok dari oprasionalnya. Kegiatan simpan pinjam adalah kegiatan menghimpun dan menyalurkan dana dari masyarakat desa. Namun, persaingan usaha simpan pinjam di wilayah pedesaan sangat ketat karena lingkup masyarakat yang relatif kecil dan juga banyaknya badan usaha yang juga menyediakan jasa simpan pinjam seperti: Koperasi, LPD, Pegadaian, dan lain-lain.

BUM Desa di Kecamatan Sawan harus mampu untuk menumbuhkan kepercayaan masyarakat desa agar dapat bersaing dengan lembaga keuangan lainnya. Laporan keuangan adalah salah satu alat yang dapat digunakan untuk membangun kepercayaan masyarakat. Pernyataan ini didukung dengan pendapat Mentri Keuangan (Menkeu) Sri Mulyani Indrawati "kalau neraca dan laporan keuangan baik maka rakyat percaya. Kalau laporan keuangan buruk maka masyarakat akan resah" (dalam acara seminar nasional yang diselenggarakan saat Peringatan Hari Oeang ke-71).

Setiap BUM Desa diberi wewenang dan kewajiban untuk menyediakan laporan keuangan sesuai dengan amanat dari UU No. 4 tahun 2015 Bab III pasal 12 ayat 3 yang menyatakan bahwa "pelaksana operasional berwenang membuat laporan keuangan seluruh unit usaha BUM Desa setiap bulannya" serta amanat dari Peraturan Mentri Dalam Negeri Nomer 20 Tahun 2018 yang mewajibkan adanya laporan pertanggungjawaban Alokasi Dana Desa pada program pemberdayaan. Laporan keuangan yang baik adalah laporan keuangan yang memiliki nilai manfaat positif bagi penggunanya dalam PSAK menyebutkan bahwa kriteria kualitas informasi yang menjadikan informasi dalam laporan keuangan BUM Desa mempunyai nilai dan manfaat yang terdiri dari: (1) relevan, (2) andal, (3) dapat dibandingkan dan (4) dapat dipahami.

Faktanya di lapangan, ternyata masih ada BUM Desa yang merasa kesulitan dalam memenuhi kewajiban tersebut. Kordinator di bidang PEMDES pada Dinas Pemberdayaan Masyarakat dan Desa kabupaten buleleng menyatakan bahwa, masih banyak BUM Desa di Kecamatan Sawan yang bermasalah dan perlu mendapatkan pengawasan. Beberapa kasus yang terjadi pada BUM Desa kecamatan sawan yaitu, pengelola BUM Desa tidak dapat mempertanggung jawabkan ketidak seimbangan neraca yang diakibatkan oleh kesalahan pencatatan, salah saji yang ditimbulkan diakui dapat merugikan BUM Desa dalam jangka pendek ataupun dalam jangka panjang. Kordinator BUM Desa juga menyatakan masalah lain yang sering terjadi yaitu masih banyak BUM Desa yang terlambat dalam melaporkan laporan keuangan mulai dari laporan bulanan hingga laporan tahunan. Hal ini didukung dengan informasi perkembangan BUM Desa pada tabel 1 yaitu sebagai berikut:

Tabel 1. Data Perkembangan BUM Desa Di Kecamatan Sawan

\begin{tabular}{llll}
\hline No. & \multicolumn{1}{c}{ Desa } & \multicolumn{1}{c}{ Nama BUM Desa } & \multicolumn{1}{c}{ Keterangan } \\
\hline 1. & Desa Lemukih & Giri Mekar & Berkembang. \\
\hline 2. & Desa Galungan & Wana Amertha & Bermasalah. \\
\hline 3. & Desa Sekumpul & Sekar Bang & Berkembang. \\
\hline 4. & Desa Bebetin & Banwa Bharu & Bermasalah. \\
\hline 5. & Desa Sawan & Swadesi & Berkembang. \\
\hline 6. & Desa Menyali & Laksadana Menyali & Berkembang. \\
\hline 7. & Desa Jagaraga & Suka Pura & Berkembang. \\
\hline
\end{tabular}




\begin{tabular}{llll}
\hline 8. & Desa Girimas & Labdajaya & Baru terbentuk. \\
\hline 9. & Desa Sangsit & Sidi Amerta & Berkembang. \\
\hline 10. & Desa Bungkulan & Kusuma Asri & Bermasalah. \\
\hline 11. & Desa Kerobokan & Sida Molih & Kurang Berkembang. \\
\hline 12. & Desa Sinabun & Sari Guna Amertha & Bermasalah. \\
\hline 13. & Desa Sudaji & Muncul Sari Aji & Bermasalah.
\end{tabular}

(Sumber : Dinas Pemberdayaan Masyarakat dan Desa Kabupaten Buleleng, 2021)

Sumber daya manusia adalah faktor utama yang memiliki peran penting dan bertanggungjawab pada baik atau buruknya kualitas laporan keuangan. BUM Desa mengalami kesulitan dalam perekrutan Sumber Daya Manusia yang berkompeten dan handal. Sebagian besar perekrutan SDM BUM Desa dilakukan dengan cara kesukarelaan sehingga masih ada pengelola BUM Desa tidak bekerja sesuai bidang profesi, tidak memiliki kompetensi yang memadai serta mereka juga tidak memiliki pengalaman bekerja di unit keuangan. Keterbatasan SDM yang handal menyebabkan timbulnya masalah, seperti kesalahan pencatatan dan alokasi asset, kurangnya kemampuan SDM dalam tata administrasi serta kurangnya evaluasi kinerja .

Teori yang mendasari pada penelitian ini adalah teori agensi. Penelitian ini mengkaji bagaimana seorang agen memberikan keyakinan kepada para principal untuk mengatasi masalah keagenan yang sering terjadi. Laporan keuangan merupakan salah satu alat pertanggungjawaban yang dapat digunakan untuk meyakinkan para principal bahwa para agen sudah memberikan kinerja yang maksimal dan sesuai dengan perturan yang berlaku. Teori ini juga didukung dengan teori kegunaan keputusan. Teori kegunaan keputusan mengkaji bagaimana laporan keuangan dapat disajikan secara profesional oleh agen yang memiliki kompetensi dan pengalaman kerja yang memadai agar dapat memiliki nilai manfaat. Agar laporan keuangan memiliki nilai manfaat maka dibutuhkan sumber daya manusia yang handal yaitu dapat menyusun laporan keuangan secara profesional didukung dengan kompetensi dan pengalaman kerja yang dimiliki.

Penelitian ini merupakan pengembangan penelitian yang dilakukan oleh (Sukriani, 2019). Perbedaan penelitian ini dengan penelitian terdahulu terletak pada variabel bebas dan lokasi penelitian. Perbedaan pada variable bebas yaitu dengan menambahkan variabel baru seperti profesionalisme dan kompetensi dan menghilangkan dua variabel yaitu tingkat pendidikan dan penggunaan teknologi informasi. Penggunaan variabel profesionalisme dan kompetensi sebagai variabel baru karena terjadi ketidakonsistenan pada hasil penelitian terdahulu sehingga peneliti ingin menguji kembali variabel ini. Perbedaan kedua pada penelitian ini yaitu terletak pada lokasi penelitian. Dimana penelitian terdahulu dilakukan di BUM Desa se-Kecamatan Negara, namun penelitian ini dilakukan pada BUM Desa seKecamatan Sawan untuk mengetahui temuan terbaru apakah variabel bebas yang diuji memberikan pengaruh terhadap laporan keuangan BUM Desa se-Kecamatan Sawan dengan permasalahan yang berbeda.

Berdasarkan uraian-uraian yang dikemukakan sebelumnya, rumusan masalah yang bisa dibahas dalam penelitian ini adalah (1) Apakah profesionalisme berpengaruh terhadap kualitas laporan keuangan; (2) Apakah kompetensi berpengaruh terhadap kualitas laporan keuangan; (3) Apakah pengalaman kerja berpengaruh terhadap kualitas laporankeuangan. Berdasarkan rumusan masalah di atas, adapun tujuan penelitian ini adalah untuk mengetahui pengaruh profesionalisme, kompetensi , dan pengalaman kerja secara parsial terhadap kualitas laporan keuangan. 
Profesionalisme dapat diartikan sikap dan prilaku seseorang dalam menjalankan profesinya dengan kesungguhan dan tanggung jawab serta memelihara citra publik (Gusfiardi, 2019). Seseorang yang memiliki sikap profesionalisme adalah mereka yang mampu memposisikan dirinya untuk memahami tugas dan tanggungjawab, hubungan dan relasi, serta fokus dan konsisten terhadap pekerjaannya. Berdasarkan teori keagenan untuk menjaga hubungan antara agen dan principal dibutuhkan laporan keuangan yang berkualitas. Sejalan dengan teori kegunaan keputusan yang menyatakan agar laporan keuangan memiliki manfaat maka harus disusun secara profesional. profesionalisme sebagai faktor penentu. Semakin tinggi faktor penentu tersebut maka hubungan antara agen dan principal akan terjaga.

Penelitian mengenai profesionalisme pernah dilakukan oleh Rahayu (2017); Basar (2017); dan Kusuma (2012) yang mengungkapkan bahwa profesionalisme secara signifikan berpengaruh positif terhadap kualitas laporan keuangan. Berdasarkan penjelasan di atas, maka hipotesis pertama yang diajukan adalah:

$\mathrm{H}_{1}$ : Profesionalisme berpengaruh positif dan signifikan terhadap laporan keuangan.

Kompetensi menurut UU No.13 Tahun 2013 adalah kemampuan kerja setiap individu yang mencakup pengetahuan, keterampilan, dan sikap kerja sesuai dengan standar yang ditetapkan. Dengan memiliki kompetensi yang baik dibidang akuntansi maka kualitas laporan keuangan suatu perusahaan akan menjadi lebih handal. Berdasarkan teori keagenan untuk menjaga hubungan antara agen dan principal dibutuhkan laporan keuangan yang berkualitas. Sejalan dengan teori kegunaan keputusan yang menyatakan agar laporan keuangan memiliki manfaat maka harus disusun kompetensi atau pengetahuan yang memadai. Kompetensi sebagai faktor penentu. Semakin tinggi faktor penentu tersebut maka hubungan antara agen dan principal akan terjaga.

Penelitian mengenai kompetensi pernah dilakukan oleh Ningrum (2018); Pujanira (2017); dan Wirawan (2016) yang mengungkapkan bahwa kompetensi secara signifikan berpengaruh positif terhadap kualitas laporan keuangan. Berdasarkan penjelasan di atas, maka hipotesis kedua yang diajukan adalah:

$\mathrm{H}_{2}$ : kompetensi berpengaruh positif dan signifikan terhadap laporan keuangan.

Potensi penuh akan muncul bertahap seiring berjalannya waktu sebagai tanggapan terhadap bermacam-macam pengalaman (Budiono.dkk, 2018). Maka pada hakikatnya pengalaman adalah pemahaman terhadap sesuatu yang dihayati dan dengan penghayatan serta serangkaian pekerjaan yang dilakukan secara terus-menerus mereka akan memperoleh pelajaran, ilmu, ketrampilan ataupun nilai yang menyatu pada potensi. Berdasarkan teori keagenan untuk menjaga hubungan antara agen dan principal dibutuhkan laporan keuangan yang berkualitas. Sejalan dengan teori kegunaan keputusan yang menyatakan agar laporan keuangan memiliki nilai manfaat maka dibutuhkan pengalaman kerja dibidang akuntansi sehingga penyusunan laporan keuangan dapat dilakukan secara efektif dan efisien. Pengalaman kerja sebagai faktor penentu. Semakin tinggi faktor penentu tersebut maka hubungan antara agen dan principal akan terjaga.

Penelitian mengenai pengalaman kerja pernah dilakukan oleh Sukriani (2019); Gusfiardi,dkk (2019); Wirawan (2016); dan Kusuma (2012) yang mengungkapkan bahwa pengalaman kerja secara signifikan berpengaruh positif terhadap kualitas laporan keuangan. Berdasarkan penjelasan di atas, maka hipotesis ketiga yang diajukan adalah:

$\mathrm{H}_{3}$ : pengalaman kerja berpengaruh positif dan signifikan terhadap laporan keuangan. 


\section{Metode}

Tempat pelaksanaan penelitian ini adalah pada Badan Usaha Milik Desa di Kecamatan Sawan. Rancangan penelitian yang digunakan adalah metode penelitian kuantitatif. Seluruh karyawan Badan Usaha Milik Desa (BUM Desa) di Kecamatan Sawan menjadi populasi dalam penelitian ini. Metode penentuan sampel yang digunakan yakni purposive sampling. Pengurus BUM Desa (ketua, sekertaris dan bendahara) adalah keriteria yang dijadikan sampel dalam penelitian ini, sehingga jumlah responden sebanyak 39 orang. Sumber data dalam penelitian ini adalah berupa data primer yaitu data yang diperoleh dari penyebaran kuesioner. Data yang terkumpul diuji terlebih dahulu dengan uji statistik deskriptif, uji kualitas data, uji asumsi klasik, dan uji hipotesis. Data yang dikumpulkan dalam penelitian ini diolah menggunakan bantuan program IBM SPSS 20 for window.

\section{Hasil dan Pembahasan}

Hasil pada penelitian ini meliputi hasil uji statistik deskriptif, uji kualitas data, uji asumsi klasik, dan uji hipotesis. Uji statistik deskriptif dilakukan untuk mengetahui nilai minimum, maksimun, mean dan standar deviasi. Hasil uji statistik deskriptif disajikan pada tabel 2 berikut:

Tabel 2. Hasil Analisis Statistik Deskriptif

\begin{tabular}{lccccc}
\hline & N & Minimum & Maximum & Mean & $\begin{array}{c}\text { Std. } \\
\text { Deviation }\end{array}$ \\
\hline Profesionalisme & 37 & 31 & 50 & 42,81 & 4,737 \\
Kompetensi & 37 & 30 & 49 & 43,08 & 4,579 \\
Pengalaman Kerja & 37 & 30 & 49 & 41,05 & 4,624 \\
Kualitas Laporan Keuangan & 37 & 30 & 50 & 42,68 & 4,703 \\
\hline
\end{tabular}

Sumber : Data Diolah, 2021

Berdasarkan hasil penelitian diatas data profesionalisme menunjukkan skor minimum 31 dan skor maksimum 50. Skor rata-rata 42,81 dengan standar deviasi sebesar 4,737. Data kompetensi menunjukkan skor minimum 30 dan skor maksimum 49. Skor rata-rata 43,08 dengan standar deviasi sebesar 4,579. Data pengalaman kerja menunjukkan skor minimum 30 dan skor maksimum 49. Skor rata-rata 41,05 dengan standar deviasi sebesar 4,624. Serta variabel kualitas laporan keuangan menunjukkan skor minimum 30 dan skor maksimum 50. Skor rata-rata 42,68 dengan standar deviasi sebesar 4,703. Hal ini menunjukkan bahwa variabel bebas (profesionalisme, kompetensi, pengalaman kerja) dan variabel terikat (kualitas laporan keuangan) memiliki standar deviasi dengan skor lebih kecil dari pada skor rata-rata yang berarti bahwa penyebaran data semua variabel bebas dan terikat pada penelitian ini berdistribusi merata, artinya selisih data satu dengan lainnya tidak terlalu jauh/tinggi. Selanjutnya dilakukan uji kualitas data.

Tingkat kualitas suatu kuesioner dapat diukur dengan uji validitas. Item pernytaan dinyatakan valid apabila rhitung $>$ rtabel atau nilai Sig. (2-tailed) $<0,05$. Jumlah sampel $(N)$ yang digunakan yaitu 39 , sehingga $\mathrm{df}=\mathrm{n}-\mathrm{k}-1=37-3-1$, sehingga diperoleh rtabel dengan $\mathrm{df}$ = 33 yaitu sebesar 2,03452. Maka diperoleh rtabel sebesar 0,1793. Dari hasil pengujian validitas pada setiap variabel diperoleh rhitung $>$ rtabel serta nilai Sig. (2- tailed) $<0,05$, sehingga bisa ditarik kesimpulan bahwa seluruh item pernyataan untuk setiap variabel adalah valid.

Uji reliabilitas digunakan untuk mengetahui adanya konsistensi setiap jawaban responden. Suatu angket dinyatakan reliabel apabila nilai Cronbach's Alpha > 0,70 (Ghozali, 2011). Berdasarkan hasil pengujian pada setiap variabel menunjukkan nilai Cronbach's Alpha 
seluruhnya di atas 0,70 sehingga dapat disimpulkan bahwa kuesioner profesionalisme, kompetensi, pengalaman kerja, dan kualitas laporan keuangan adalah reliabe. Selanjutnya dilakukan uji asumsi klasik.

Uji normalitas dilakukan untuk mengecek apakah pada model regresi suatu variabel dependen dan variabel independen terdistribusi secara normal atau tidak (Ghozali, 2011). Uji normalitas menggunakan Kolmogorov-Smirnov (K-S). Bersumber dari tabel 3 menunjukkan bahwa nilai dari tes statistik Kolmogrov Smirnov (K-S) yaitu sebesar 0,802 dan nilai (Asymp. Sig. (2-tailed) sebesar 0,540 Hal ini berarti nilai signifikansi (Asymp. Sig. (2-tailed) lebih besarr dari $0,05(0,540>0,05)$. Sehingga dalam hal ini dapat dikatakan data terdistribusi secara normal

Tabel 3. Hasil Uji Normalitas

\begin{tabular}{lll}
\hline & & $\begin{array}{l}\text { Unstandardized } \\
\text { Residual }\end{array}$ \\
\hline $\mathrm{N}$ & & 37 \\
Normal Parameters ${ }^{\mathrm{a}, \mathrm{b}}$ & Mean & $0 \mathrm{E}-7$ \\
& Std. Deviation & 0,87855742 \\
Most Extreme Differences & Absolute & 0,132 \\
& Positive & 0,132 \\
& Negative & $-0,105$ \\
Kolmogorov-Smirnov $\mathrm{Z}$ & & 0,802 \\
Asymp. Sig. (2-tailed) & & 0,540 \\
\hline
\end{tabular}

Sumber : Data diolah, 2021

Uji multikolinearitas yang bertujuan untuk menguji apakah model regresi ditemukan adanya korelasi antar variabel bebas atau tidak. Berdasarkan tabel 4 dapat dilihat bahwa nilai tolerance pada setiap variabel bebas $>0,10$. Demikian pula dengan nilai VIF pada setiap variabel bebas memiliki nilai $<10$. Sehingga disimpulkan bahwa tidak terjadi multikolonearitas pada model regresi.Berikut hasil uji multikolinearitas :

Tabel 4. Hasil Uji Multikolinearitas

\begin{tabular}{lccc}
\hline \multirow{2}{*}{ Model } & \multicolumn{2}{c}{ Collinearity Statistics } & Keterangan \\
\cline { 2 - 3 } & Tolerance & VIF & \\
\hline Profesionalisme & 0,160 & 9,452 & \\
Kompetensi & 0,120 & 8,330 & \\
Pengalaman Kerja & 0,255 & 3,923 & Bebas Multikolinearitas \\
\hline
\end{tabular}

Sumber : Data Diolah, 2021

Uji heteroskedastisitas bertujuan untuk mengetahui apakah model regresi terjadi ketidaksamaan varian dari residual satu pengamatan ke pengamatan lain. Cara yang digunakan untuk mendeteksiadanya heteroskedastisitas adalah dengan menggunakan uji Glejser. Berdasarkan tabel 5 dapat dilihat bahwa nilai signifikan seluruh variabel memiliki nilai $>0,05$. Sehingga dapat disimpulkan bahwa model regresi tidak mengandung adanya heteroskedastisitas.Berikut ini merupakan hasil dari uji heteroskedastisitas : 
Tabel 5. Hasil Uji Heteroskedastisitas

\begin{tabular}{lc}
\hline \multicolumn{1}{c}{ Model } & Sig. \\
\hline Profesionalisme & 0,496 \\
Kompetensi & 0,076 \\
Pengalaman Kerja & 0,074 \\
\hline
\end{tabular}

Sumber : Data Diolah, 2021

Selanjutnya dilakukan pengujian hipotesis. Analisis regresi linear berganda digunakan untuk melihat pengaruh beberapa variabel bebas terhadap variabel terikat. Model regresi dalam penelitian ini adalah menguji variabel profesionalisme (X1), kompetensi (X2), dan pengalaman kerja (X3) terhadap kualitas laporan keuangan BUM Des (Y). Hasil uji regresi linear berganda dapat dilihat pada tabel 6 berikut ini :

Tabel 6. Hasil Analisis Regresi Linear Berganda

\begin{tabular}{|c|c|c|c|}
\hline Model & $\begin{array}{c}\begin{array}{c}\text { Unstandardized } \\
\text { Coefficients }\end{array} \\
\text { B }\end{array}$ & $t$ & Sig. \\
\hline (constant) & $-1,187$ & $-0,806$ & 0,426 \\
\hline Profesionalisme & 0,389 & 3,918 & 0,000 \\
\hline Kompetensi & 0,445 & 4,619 & 0,000 \\
\hline Pengalaman Kerja & 0,196 & 2,985 & 0,005 \\
\hline
\end{tabular}

Sumber : Data Diolah, 2021

Berdasarkan hasil uji diatas dapat ditentukan persamaan garis regresi linear berganda dari pola pengaruh variabel profesionalisme, kompetensi dan pengalaman kerja terhadap kualitas laporan keuangan BUM Des yang dapat dinyatakan dengan persamaan regresi sebagai berikut:

$$
\begin{aligned}
& \mathrm{Y}=\alpha+\beta 1 \mathrm{X} 1+\beta 2 \mathrm{X} 2+\beta 3 \mathrm{X} 3+\beta 4 \mathrm{X} 4+\varepsilon \ldots \\
& \mathrm{Y}=-1,187+0,389 \mathrm{X} 1+0,445 \mathrm{X} 2+0,196 \mathrm{X} 3+
\end{aligned}
$$

Dapat dilihat nilai konstanta $(\alpha)$ sebesar $-1,187$ yang menyatakan bahwa apabila variabel independen profesionalisme (X1), kompetensi (X2), dan pengalaman kerja (X3) memiliki nilai 0 (nol), maka variabel dependen kualitas laporan keuangan BUM Des (Y) mengalami penurunan sebesar nilai konstanta tersebut. Koefisien regresi variabel profesionalisme (X1) diperoleh hasil sebesar 0,389 yang artinya variabel independen profesionalisme (X1) naik sebesar 1 satuan dengan asumsi bahwa variabel bebas lainnya konstan, maka variabel kualitas laporan keuangan BUM Des (Y) akan mengalami kenaikan sebesar 0,389 satuan. Koefisen regresi kompetensi (X2) diperoleh hasil sebesar 0,445 yang artinya variabel independen kompetensi (X2) naik sebesar 1 satuan dengan asumsi bahwa variabel bebas lainnya konstan, maka variabel kualitas laporan keuangan BUMDes (Y) akan mengalami kenaikan sebesar 0,445 satuan. Koefisien regresi pengalaman kerja (X3) diperoleh hasil sebesar 0,196 yang artinya variabel independen pelatihan (X3) naik sebesar 1 satuan dengan asumsi bahwa variabel bebas lainnya konstan, maka variabel kualitas laporan keuangan BUM Des (Y) akan mengalami kenaikan sebesar 0,196 satuan. 
Uji koefisen determinasi (Adjusted R), dimana uji ini mengukur seberapa jauh kemampuan model dalam menerangkan variabel independen. Berikut merupakan hasil pengujian koefisien determinasi yang dapat dilihat pada tabel 7 :

Tabel 7. Hasil Uji Koefisien Determinasi

\begin{tabular}{cc}
\hline Model & Adjusted $R$ Square \\
\hline 1 & 0,962 \\
\hline Sumber : Data Diolah, 2021
\end{tabular}

Berdasarkan hasil uji koefisien determinasi dapat diketahui bahwa nilai Adjusted $\mathrm{R}$ Square sebesar 0,962 yang mengandung arti bahwa 96,2\% variasi besarnya kualitas laporan keuangan BUM Desa dapat dijelaskan oleh variasi independen yaitu profesionalisme, kompetensi, dan pengalaman kerja. Sedangkan sisanya sebesar 3,8\% dipengaruhi oleh variabel lain yang tidak diteliti dalam penelitian ini.

Uji t menunjukkan seberapa jauh pengaruh satu variabel penjelas dan independen secara individu dalam menjelaskan variansi variabel dependen (Ghozali, 2009). Penetapan untuk mengetahui hipotesis diterima atau ditolak dilakukan dengan cara membandingkan thitung dengan ttabel dengan taraf signifikansi 0,05. Dalam penelitian ini menggunakan 39 sampel dengan data yang dapat diolah sebesar 37 sehingga diperoleh $\mathrm{df}=\mathrm{n}-\mathrm{k}-1=37-3-1$, sehingga diperoleh ttabel dengan $\mathrm{df}=33$ yaitu sebesar 2,03452. Hasil uji t (secara parsial) disajikan pada tabel 4 diatas.

Variabel profesionalisme menunjukkan bahwa nilai thitung lebih besar dari ttabel, yaitu sebesar 3,918> 2,03452 dan nilai signifikansi profesionalisme sebesar 0,000<0,05. Berdasarkan hasil tersebut maka, H1 diterima yang berarti variabel profesionalisme berpengaruh positif dan signifikan terhadap kualitas laporan keuangan BUM Desa. Variabel kompetensi menunjukkan bahwa nilai thitung lebih besar dari ttabel, yaitu sebesar 4,619 > 2,03452 dan nilai signifikansi kompetensi sebesar $0,000<0,05$. Berdasarkan hasil tersebut maka, H2 diterima yang berarti variabel kompetensi berpengaruh positif dan signifikan terhadap kualitas laporan keuangan BUM Desa. Variabel pengalaman kerja menunjukkan bahwa nilai thitung lebih besar dari ttabel, yaitu sebesar 2,985>2,03452 dan nilai signifikansi pengalaman kerja sebesar 0,005 <0,05. Berdasarkan hasil tersebut maka, H3 diterima yang berarti variabel pengalaman kerja berpengaruh positif dan signifikan terhadap kualitas laporan keuangan BUM Desa.

\section{Pengaruh Profesionalisme Terhadap Kualitas Laporan Keuangan BUM Desa}

Berdasarkan hasil pengujian hipotesis pada uji statistik t, dapat disimpulkan bahwa $\mathrm{H} 1$ diterima sehingga profesionalisme berpengaruh positif dan signifikan terhadap kualitas laporan keuangan. Apabila pengurus BUM Desa bekerja sesuai kemampuan dan keahlian yang dibutuhkan maka akan meningkatkan kualitas laporan keuangan.

Hasil penelitian ini sesuai dengan teori keagenan dan teori kegunaan keputusan dimana menghasilkan laporan keuangan yang berkualitas merupakan tujuan organisasi yang ingin dicapai untuk menjaga hubungan antara agen dan principal, sedangkan profesionalisme sebagai faktor penentu. Semakin tinggi faktor penentu tersebut maka akan semakin tinggi pula kemungkinan tujuan organisasi lebih mudah tercapai.

Karyawan BUM Desa telah memiliki profesionalisme yang cukup tinggi dengan mengembangkan keahliannya dalam pelaksanaan kerjanya. Profesionalisme yang tinggi 
mampu mendukung dalam menjalankan tugasnya yaitu menyusun laporan keuangn yang berkualitas.

Hasil dari penelitian ini sejalan dengan hasil penelitian yang dilakukan oleh Rahayu (2017); Basar (2017) ; dan Kusuma (2012) yang menyatakan bahwa profesionalisme berpengaruh positif dan signifikan terhadap kualitas laporan keuangan.

\section{Pengaruh Kompetensi Terhadap Kualitas Laporan Keuangan BUM Desa.}

Berdasarkan hasil pengujian hipotesis pada uji statistik t, dapat disimpulkan bahwa $\mathrm{H} 2$ diterima sehingga kompetensi berpengaruh positif dan signifikan terhadap kualitas laporan keuangan. Apabila pengurus BUM Desa bekerja didukung dengan kompetensi dan pengetahuan yang memadai maka akan meningkatkan kualitas laporan keuangan.

Hasil penelitian ini sesuai dengan teori keagenan dan teori kegunaan keputusan dimana semakin tinggi tingkat kompetensi yang dimiliki pengurus, maka kemungkinan untuk menghasilkan laporan keuangan yang berkualitas akan tercapai sehingga hubungan antara agen dan principal akan terjaga.

Karyawan BUM Desa telah memiliki kompetensi yang memadai dengan mengikuti pelatihan tentang laporan keuangan. Memiliki kompetensi yang tinggi akan memperkecil tingkat kesalahan yang dilakukan pengurus dalam menyusun laporan keuangan .

Hasil dari penelitian ini sejalan dengan penelitian yang dilakukan oleh Ningrum (2018); Pujanira (2017) ;Wirawan (2016) yang mendapat hasil kompetensi memiliki pengaruh yang positif dan signifikan terhadap kualitas laporan keuangan.

\section{Pengaruh Pengalaman Kerja Terhadap Kualitas Laporan Keuangan BUM Desa.}

Berdasarkan hasil pengujian hipotesis pada uji statistik t, dapat disimpulkan bahwa H3 diterima sehingga pengalaman kerja berpengaruh positif dan signifikan terhadap kualitas laporan keuangan. Apabila pengurus BUM Desa memiliki pengalaman kerja yang relatif panjang maka mereka akan mendapatkan manfaat bekerja yang tinggi sehingga memudahkan mereka untuk menyajikan laporan keuangan yang berkualitas.

Hasil penelitian ini sesuai dengan teori keagenan dan teori kegunaan keputusan dimana semakin tinggi pengalaman kerja yang dimiliki pengurus, maka akan semakin tinggi pula kemungkinan untuk menghasilkan laporan yang berkualitas sehingga hubungan antara agen dan principal akan terjaga.

Karyawan BUM Desa telah memiliki pengalaman kerja yang cukup tinggi dengan mengamati semua kegiatan dan kemudian menjadikannya sebagai pelajaran untuk dikemudian hari. Pengalaman kerja akan membantu pengurus dalam menyusun laporan keuangan agar tepat waktu.

Hasil dari penelitian ini sejalan dengan penelitian yang dilakukan oleh Sukriani (2019); Gusfiardi, dkk (2019); Wirawan (2016) ; dan Kusuma (2012) yang menyatakan bahwa pengalaman kerja berpengaruh positif dan signifikan terhadap kualitas laporan keuangan.

\section{Simpulan dan Saran}

Berdasarkan hasil penelitian dan pembahasan yang telah dipaparkan, maka dapat disimpulkan yaitu 1) Pengujian hipotesis pertama menunjukkan hasil bahwa profesionalisme berpengaruh positif dan signifikan terhadap kualitas laporan keuangan. Profesionalisme yaitu sikap yang dimiliki seseorang yang profesional dalam bekerja, dimana tugasnya sesuai dengan kemampuan yang dimiliki sehingga semakin baik profesionalisme pegawai, maka semakin baik kualitas laporan keuangan yang dihasilkan, 2) Pengujian hipotesis kedua menunjukkan hasil bahwa kompetensi berpengaruh positif dan signifikan terhadap kualitas 
laporan keuangan. Pegawai yang memiliki pengetahuan, keterampilan, dan sikap yang sesuai dalam bidangnya terutama akuntansi, maka semakin baik kualitas laporan keuangan yang dihasilkan, 3) Pengujian hipotesis ketiga menunjukkan hasil bahwa pengalaman kerja berpengaruh positif dan signifikan terhadap kualitas laporan keuangan. Apabila pegawai yang direkrut memiliki pengalaman di bidangnya, akan menghasilkan kualitas laporan keuangan yang lebih baik dibanding pegawai yang baru memasuki dunia kerja.

Adapun saran yang dapat penulis sampaikan yaitu 1) Bagi Dinas Pemerdayaan Masyarakat dan Desa dan instansi pemerintah disarankan untuk dapat meningkatkan kegiatan monitoring dan evaluasi terhadap BUM Des agar dapat dilakukan secara periodik terhadap BUM Des tersebut dan diharapkan agar lebih meningkatkan pelatihan serta pembinaan terkait dengan pengelolaan keuangan pada BUM Des untuk dapat meningkatkan pemahaman bagi pengelola BUM Des mengenai pengelolaan keuangan khususnya pada penyusunan dan penyajian laporan keuangan pada BUM Des, 2) Badan Usaha Milik Desa agar dapat memperhatikan pegawai ataupun pengurus BUM Desa. BUM Desa diharapkan dapat melakukan kegiatan-kegiatan diluar pekerjaan seperti gathering untuk meningkatkan relasi atau hubungan dengan pekerja lain yang seprofesi se-kecamatan Sawan, sehingga terjalin relasi yang baik dan dapat berbagi informasi. Selain itu, pengurus BUM Desa diharapkan dapat lebih tegas dalam mengatur pengurus lainnya maupun anggota agar dapat bertanggung jawab terhadap pekerjaan sesuai dengan kompetensi yang mereka miliki. Karyawan yang memiliki pengalaman kerja dan bekerja dengan baik, agar diberikan bonus sehingga karyawan dapat merasakan manfaat pengalaman kerja yang mereka milik, dan 3) Bagi penelitian selanjutnya diharapkan dapat memaksimalkan hasil penelitian dengan menguj variabel lain, memperluas objek penelitian dan jumlah sampel.

\section{Daftar Pustaka}

Basar, Nurfatwa. 2018. Pengaruh Profesionalisme Aparat Inspektorat Terhadat Kualitas Laporan Keuangan Pemerintah Daerah Kabupaten Gowa.Jurnal Economix Volume 5 Nomor 1.

Budiono, Shabrina., Muchlis, dan Masri,Indah. 2018.Analisis Pengaruh Pendidikan dan Pelatihan, Pengalaman Kerja Serta Pemanfaatan Teknologi Informasi Terhadap Kualitas Laporan Keuangan Pemerintah Daerah (Studi Kasus Pada Pemerintah Kota Depok). JURNAL ILMIAH WAHANA AKUNTANSI,Vol 13 (2), 110-128.

Ghozali, Imam. 2009. Aplikasi Analisis Multivariate Dengan program SPSS. Edisi Kedua. Semarang: Badan Penerbit Universitas Diponegoro.

Gusfiardi,dkk. 2019. Pengaruh Kompetensi, Profesionalisme, dan Pengalaman Kerja Auditor Terhadap Kualitas Audit Internal Pada Perusahaan Swasta dan BUMN di Padang. Jurnal Eksplorasi Akuntansi. Universitas Negeri Padang.

Ikatan Akuntansi Indonesia. PSAK No. 1 Tentang Laporan Keuangan- edisi revisi2015. Penerbit Dewan Standar Akuntansi Keuangan: PT. Raja Grafindo.

Kementrian Keuangan Republik Indonesia. 2017. Acara Seminar Nasional. Dipresentasikan dalam Rangkaian Peringatan Hari Oeang ke-71, gedung Dhanapala, Jakarta. Diunduh Pada tanggal 25 Februari 2021. https://www.kemenkeu.go.id/publikasi /berita/menkeu-menjaga-kepercayan-rakyat-dengan-laporan-keuangan-yan g-baik/. 
Kusuma. 2012. Pengaruh Profesionalisme Auditor, Etika Profesi dan Pengalaman Auditor Terhadap Pertimbangan Tingkat Materialitas. Skripsi.Universitas Negeri Yogyakarta.

Murina, Shasa. dan Rahmawaty. 2017. Pengaruh Tingkat Pendidikan, KualitasPelatihan, dan Pengalaman Kerja Terhadap Pemahaman Laporan Keuangan Pada UMKM (Studi pada Kecamatan Banda Raya Kota Banda Aceh). Jurnal Ilmiah Mahasiswa Ekonomi Akuntansi (JIMEKA), Vol. 2, No. 3.

Ningrum,Kencana. 2018. Pengaruh Kompetensi Sumber Daya Manusia, Pemanfaatan Teknologi Informasi, dan Sistem Pegendalian Intern Terhadap Kualitas Laporan Keuangan Pemerintah Daerah Kabupaten Kebumen. Skripsi, Universitas Islam Indonesia.

Pemerintah Indonesia. 2014. Undang-undang Republik Indonesia Nomor 6 Tahun 2014 Tentang Desa. Lembaran Negara Republik Indonesia tahun 2014, No. 7. Jakarta.

Pemerintah Indonesia. 2015. Permendesa PDTT Nomor 4 Tahun 2015 tentang Badan Usaha Milik Desa.

Pemerintah Indonesia. 2018. Peraturan Mentri Dalam Negeri Nomer 20 Tahun 2018 tentang Pengelolaan Keuangan Desa.

Pujanira, Putriasri . 2017. pengaruh Kompetensi Sumber Daya Manusia, Penerapan Standar Akuntansi Pemerintah, dan Penerapan Sistem Akuntansi Keuangan Daerah Terhadap Kualitas Laporan Keuangan Pemerintah Daerah Provinsi DIY.JURNAL NOMINAL, VOLUME VI NOMOR 2 .

Rahayu, Yoni. 2017. Analisis Pengaruh Profesionalisme, Pengelolaan Keuangan Daerah, Pemanfaatan Teknologi Informasi, dan Pengendalian Internal Terhadap Kualitas Laporan Keuangan Pada Dinas Pendapatan Daerah Kabupaten Gianyar. Skripsi, Universitas Pendidikan Ganesha.

Siagian,S.P.2000. Manajemen Sumber daya Manusia, Jakarta :Bumi Aksara.

Sukriani,Luh.2019. Pengaruh Tingkat Pendidikan, Pengalaman Kerja, Pelatihan, dan Penggunaan Teknologi Informasi Terhadap Kualitas Laporan Keuangan BUMDes di Kecamatan Negara. Skripsi, Universitas Pendidikan Ganesha. 